\title{
The yeasts and yeast-like microorganisms in the denitrification unit biocenosis
}

\author{
ELENA SLÄVIKOVÄ* and ANNA GRABIŃSKA-LONIEWSKA** \\ "Institute of Chemistry, Chemical Research Center, Slovak Academy of Science, Dubravska cesta 9, \\ 842-38 Bratislava, Czechoslovakia \\ **Institute of Environmental Engineering. Warsaw Technical University. Nowowiejska 20, 00-653 \\ Warszawa, Poland
}

Slavikova E., Grabinska-toni ewska A.: The yeasis and yeast-like microorganisms in the denitrification unit biocenosis, Acta Mycol. 22(2): 177-184, 1986 (1988).

Taxonomic studies of the yeasts and yeast-like microorganisms in the denitrification unit biocehosis'were carried out. A set of 13 strains of these microorganisms were examined for their morphological and physiological characters. Considering their special features and some relation to the known species, the isolated microorganisms were classified to the 3 genera: Candida. Georrichium and Hansenula.

\section{INTRODUCTION}

The role of fungi in the removal of nitrates from waste-waters in denitrification units is at present still poorly studied. G r a b i n s k a- $\ell$ o $\mathrm{n}$ i e w s k a et al. (1985) have shown that yeasts and yeast-like microorganisms are besides bacteria the main component of a denitrification unit biocenosis. Their number in the biocenosis depends on the type and amount of carbon being the hydrogen donor in denitrification and on the technical parameters of the process such as unit nitrate load and sludge retention time (cell residence time).

This paper presents the results of taxonomic studies of yeasts and yeast-like microorganisms isolated from denitrification unit biocenosis grown in continuous system in medium with acetic acid as carbon source.

\section{MATERIALS AND METHODS}

The microorganisms were isolated by Grabinska-Loniewska in the period of X.1982-V.1983 from the biocenosis populated the denitrification unit, situated in Warsaw Technical University. A continuous culture of the biocenosis was set 
up in a laboratory single stage 2.71 volume anaerobic reactor made of organic glass. Details of the unit design have been given elsewhere ( $\mathrm{S} 1$ o m c z y n s k i and Grabińska- - on i e wsk a 1983, G r a bińsk a- $\ell$ o n i e w$\mathrm{s} \mathrm{k}$ a et. al. (1985). The reactor was inoculated with strains of denitrifying bacteria of the genera. Pseudomonas, Proteus, Agrobacterium and Alcaligenes previously isolated from the activated sludge. Synthetic medium with composition resembling Pichinoty's medium (B $r$ is o $n$ 1971) with acetic acid as a carbon source was used as a feed. The medium contained (in $\mathrm{mg} \times 1^{-1}$ ): $\mathrm{NO}_{3}-\mathrm{N}$ (as $\mathrm{KNO}_{3}$ )-600; $\mathrm{PO}_{4}^{3-}$ (as $\mathrm{Na}_{2} \mathrm{HPO}_{4} \times 12 \mathrm{H}_{2} \mathrm{O}$ and $\mathrm{KH}_{2} \mathrm{PO}_{4}$ )-700, $\mathrm{Mg}^{2+}$ (as $\mathrm{MgSO}_{4}$ )-2.4. The concentration of the carbon source in the medium was $1300-1900 \mathrm{mg} \mathrm{l}^{-1}$. Denitrification involved continuous feeding of the medium, without recycling of biomass. The $\mathrm{pH}$ of the culture in the reactor was maintained at 6.9-7.1 and the redox potential $\left(\mathrm{E}_{\mathrm{h}}\right)$ within the range -100 and $-300 \mathrm{mV}$. The process was performed at $20^{\circ} \mathrm{C}$.

The yeasts and yeast-like microorganisms were isolated from the denitrification unit biocenosis by enrichment cultures on a Martin's agar (after S t r z e l c z y k 1968) containing: $\mathrm{KH}_{2} \mathrm{PO}_{4}-1.0 \mathrm{~g}, \mathrm{MgSO}_{4} * 7 \mathrm{H}_{2} \mathrm{O}-0.5 \mathrm{~g}$, peptone $-5.0 \mathrm{~g}$, glucose $-10.0 \mathrm{~g}$, rose-bengal solution $(1: 300)-10 \mathrm{ml}$ and agar - $20.0 \mathrm{~g}$ in 11 distilled water. Just before inoculation the medium was supplemented with $30 \mathrm{mcg}$ streptomycin $/ \mathrm{ml}$. Samples to be plated out were treated for $15 \mathrm{~min}$ at $1000 \mathrm{rev} / \mathrm{min}$ in a Unipan type 302 homogenizer. The operating parameters ensuring adequate deflocculation of the biomass have been experimentally determined (B o ż k o et al. 1972). The plates were incubated aerobically at $28^{\circ} \mathrm{C}$ for a week. The types of colonies dominated on the plates were passaged to beer wort. Before the identification process was started repeated isolations by the Koch method were carried out.

The microorganisms were identified on the basis of their cell and culture morphology and physiological characters according to the principles suggested by Kock ova-K r a t o chvilová (1984), Kreger-va n R i j (1984), G u e h o (1979) and A r x (1977). Cell morphology was examinated using 3-day-old culture in beer wort (7\%, w/w, extract).

For the description of growth in liquid medium wort beer was used, too. Giant colonies were studied on wort agar during 3 weeks of cultivation at room temperature. The diameter of the colony was measured after 1, 7, 14 and 21 days and average radial growth rate was calculated as the increase in diameter $(\mathrm{mm})$ in $100 \mathrm{~h}$. Pseudomycelium was demonstrated on slides with onion-agar containing in 11 onion extract ( $250 \mathrm{~g}$ peeled onion boiled in 11 water and filtered) $1 \mathrm{~g}$ glucose and $15 \mathrm{~g}$ agar ( $\mathrm{L}$ a $\mathrm{n}$ ge $\mathrm{r}$ o $\mathrm{n}$ 1945). Sporulation activity was estimated on Fowell agar ( $5 \mathrm{~g}$ sodium acetate, $2.3 \mathrm{~g}$ potasium chloride and $2 \mathrm{~g}$ agar in 11 water) by counting the number of sporulation elements (spores, asci, zygotes) within a set of 500 cells. 
Fermentation of sugars was tested in Durham tubes containing $4 \mathrm{~g}$ powdered

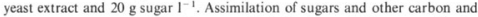
nitrogen sources was tested using respectively Bacto-yeast Nitrogen or Bacto-yeast Carbon Base agar (Difco) on the surface of which filter paper discs were placed, soaked with $50 \mathrm{~g}$ test substance $1^{-1}$ and sterilized by ultraviolet light. Assimilation of ethanol and methanol was evaluated in liquid medium with alcohol as sole source of carbon and Bacto-yeast Nitrogen Base (Difco). U rease activity was proved by colour change to red with phenol red indicator added to the growth medium with urea as a carbon source ( $\mathrm{K}$ o $c k$ o v a-K ratochvilova 1977). Vitamin requirement was tested in Bacto-vitamin-free Yeast Base (Difco): the culture was transferred twice into fresh medium in week intervals and the turbidity of the culture was then compared with that of a culture grown in medium supplemented with vitamins ( $\mathrm{L} \mathrm{o} \mathrm{d} \mathrm{d} \mathrm{e} \mathrm{r} \mathrm{1970).} \mathrm{Growth} \mathrm{at} 37^{\circ}$ (and $42^{\circ} \mathrm{C}$ in some cases) on wort agar was compared visually with cultures grown at $28^{\circ} \mathrm{C}$.

All strains are deposited in the Crechoslovak Collection of Yeasts (CCY), Institute of Chemistry SAS, Bratislava.

\section{RESULTS AND DISCUSSION}

A set of 13 strains of yeasts and yeast-like microorganisms was isolated from denitrification unit biocenosis. Basing on commonly accepted identification methods the organisms were classified to the genera Candida, Geotrichum and Hansenula. Genus Candida was dominant among them. We classified 11 strains into this genus. They were mainly represented by C. famat $a$ and C. lamhica (by four strains, each one). Description of the cell and culture morphology and some physiological characters of the isolated strains is given below. Fermentation and assimilation of different sugars and assimilation of some nitrogen compounds is summarized in Table 1.

Candida famata (Harrison) Meyer et Yarrow - strains 019.D8, 014.D8, 07.D6 and 05.D4 (CCY 29-32-2; 29-32-3; 29-32-5 and 29-32-4, respectively).

The cells are spherical to ovoid (Figs 1-4). During the growth in liquid medium a sediment is formed. The appearance of the giant colonies was greyishwhite, semidull, soft, smooth, rate of growth in $100 \mathrm{hrs}$ at $20^{\circ} \mathrm{C}$ : strain $019 . \mathrm{D} 8$ $3.72 \mathrm{~mm}$; strain 05.D4 - 3.70 mm. strain 014.D8 - 3.47 mm. strain 07.D6 - 3.94 $\mathrm{mm}$. No pseudomycelium is formed, though short branched chains of round-oval cells are produced. Sporulation was not observed. All strains did not produce of urease. They grew in vitamin-free medium. At the temperature $28^{\circ}$ and $37^{\circ} \mathrm{C}$ they grow well.

This four strains differ from standard description of $C$. famata in negative assimilation of L-arabinose and cellobiose (Table I). 
Ta ble 1

Fermentation and assimilation of some sugars and assimilation of nitrogen sources by strains of yeast and yeast-like microorganisms isolated from denitrifying unit biocenosis

\begin{tabular}{|c|c|c|c|c|c|c|c|}
\hline $\begin{array}{l}\text { Name (Number } \\
\text { of strains) }\end{array}$ & 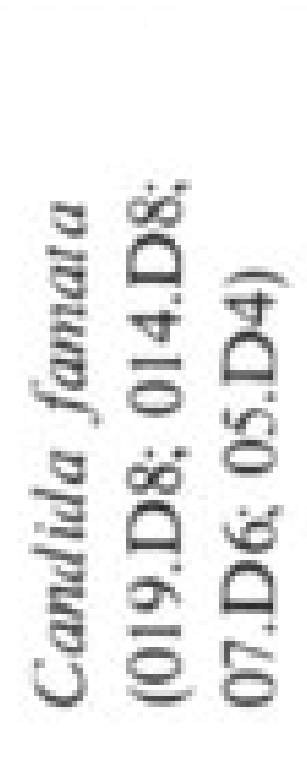 & 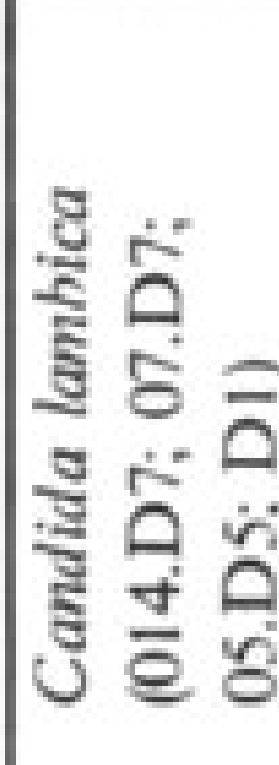 & 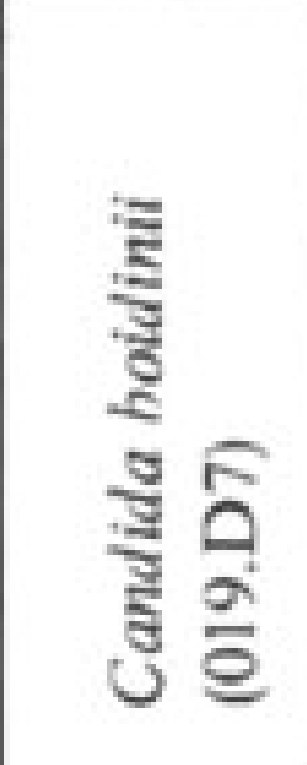 & 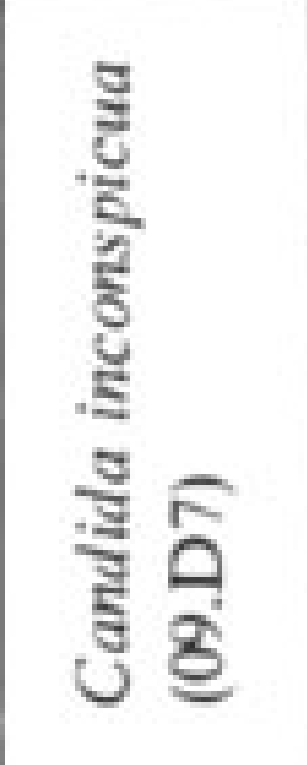 & 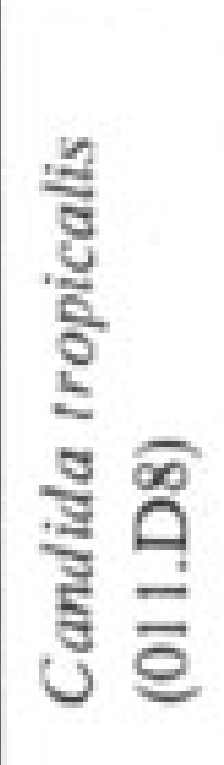 & 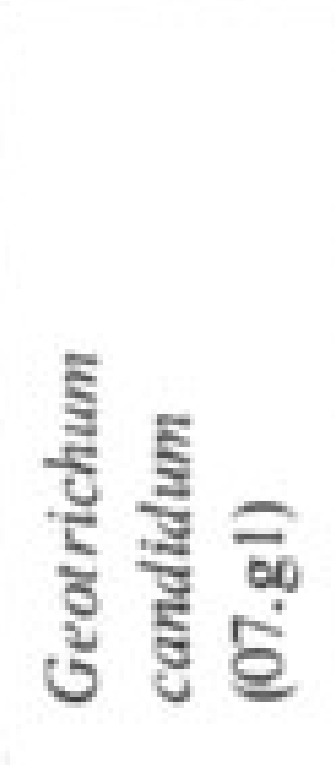 & 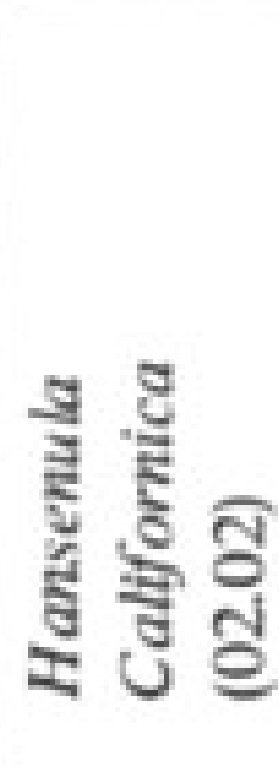 \\
\hline Fermentation: & & & & & & & \\
\hline Mal & - & - & - & - & + & - & - \\
\hline Sac & - & - & - & - & + & - & - \\
\hline Lac & - & - & - & - & - & - & - \\
\hline $\begin{array}{l}\text { Glc } \\
\text { Assimilation: }\end{array}$ & - & + & + & - & + & - & + \\
\hline Mal & + & - & - & - & + & - & + \\
\hline Sac & + & - & - & - & + & - & + \\
\hline Lac & - & - & - & - & - & - & - \\
\hline Raf & + & - & - & - & - & - & - \\
\hline $\mathrm{Mlz}$ & + & - & - & - & + & - & - \\
\hline D-Xyl & + & + & + & - & + & + & + \\
\hline L-Ara & - & - & - & - & - & - & - \\
\hline Inl & - & - & - & - & - & - & - \\
\hline $\mathrm{Aml}$ & $-*$ & - & + (weak) & - & + & - & ? \\
\hline $\mathrm{Cel}$ & - & - & - & - & + & - & + \\
\hline Tre & + & - & - & - & + & - & - \\
\hline $\mathrm{KNO}_{3}$ & - & - & + & - & - & - & + \\
\hline Lysine & + & - & + & - & + & + & - \\
\hline Trypiophane & + & - & $=$ & + (weak) & + & + & - \\
\hline
\end{tabular}

- This compound was assimilated only by the sirain 07.D6.

Abbreviaions: Gle - glucose; Mal - maltoses Sac - sucrose; Lac - laciosc Raf - rafinose Mz - melezitose D-Xyl - D-xylose; L-Ara - L-arabinose; InI - inulin; AmI - amylose, Cel - allobiose; Tre - trehalose, - test negative + test positive

Candida lambica (Lindner et Genoud) van Uden et Buck ley - strains 014.D7, 07.D7, 05.D5 and 02.D1 (CCY 29-97-2, 29-97-3, 29-97-4 and 29-97-5, respectively).

The shape of the cells is ovoid (Figs 5-8). In liquid medium a sediment and a ring are formed. Colonies are cream-coloured, soft, semidull and wrinkled (Fig. 14), rate of growth in $100 \mathrm{hrs}$ at $20^{\circ} \mathrm{C}$ : strain: 014.D7 $-3.94 \mathrm{~mm}$, strains: 07.D7, 05.D5 and 02.D1 - $5.32 \mathrm{~mm}$. Pseudomycelium is formed. Sporulation was not observed. All strains are inable to produce urease. They grew weakly in vitamin-free medium. All strains grew good at the temperature $28^{\circ} \mathrm{C}$, at $37^{\circ} \mathrm{C}$ growth was poor. 


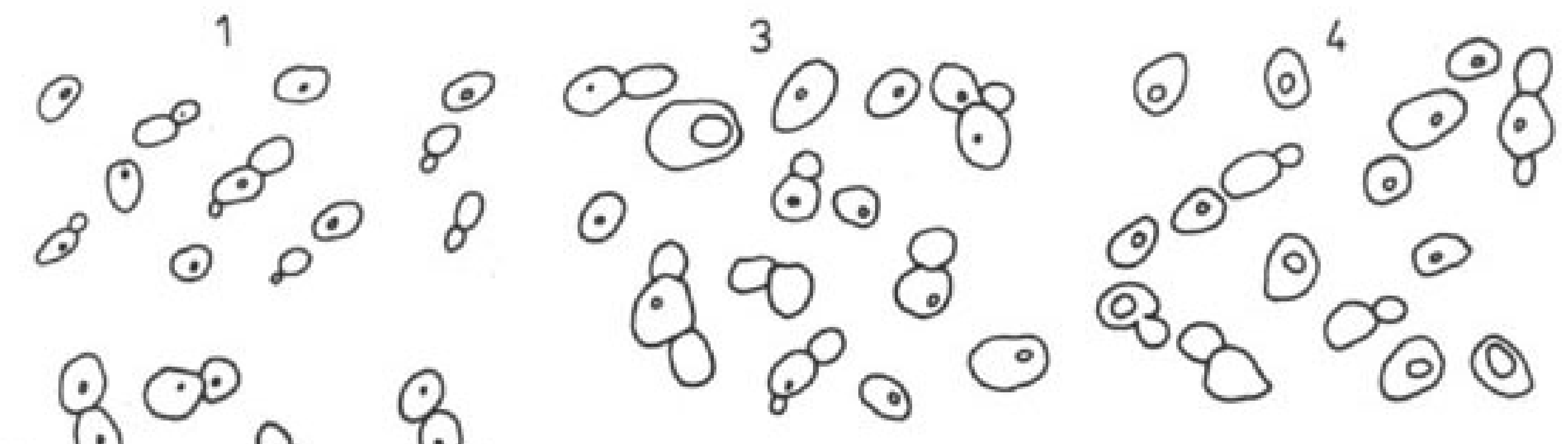
$2800^{8}$

$\odot$<smiles>O=COCCO</smiles>
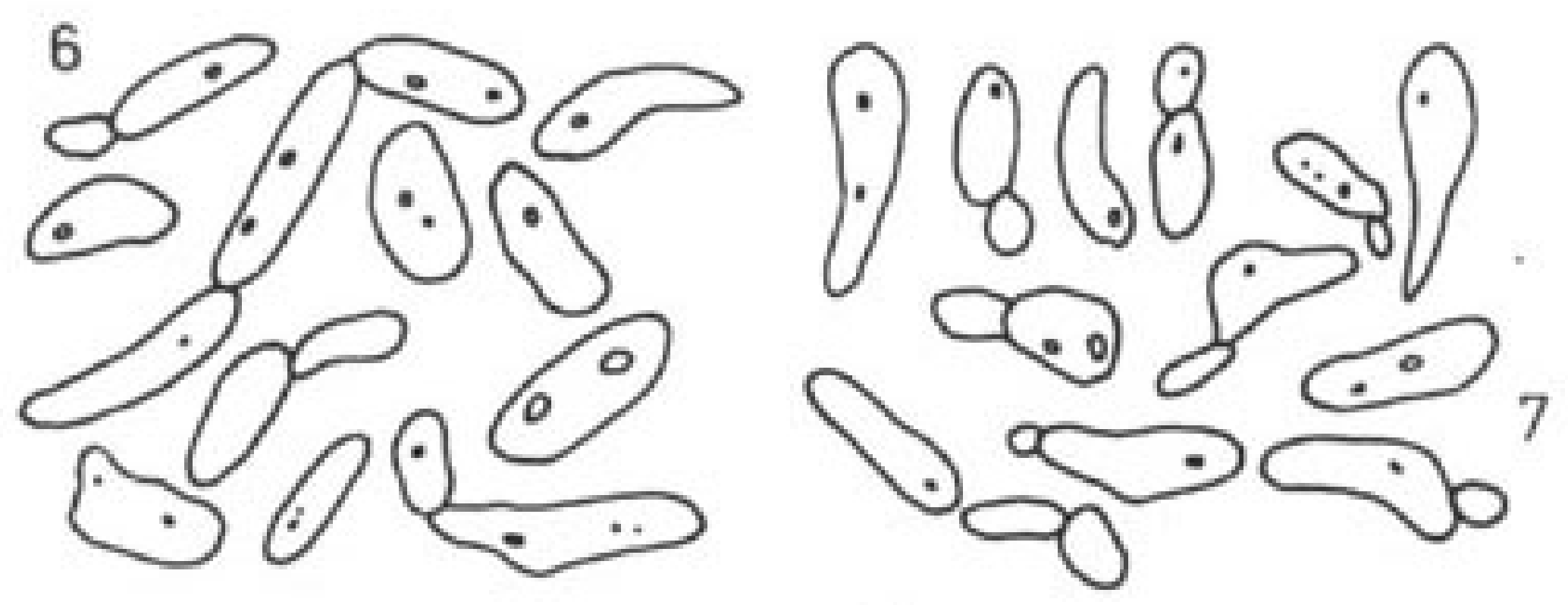

5

$0^{\circ}$
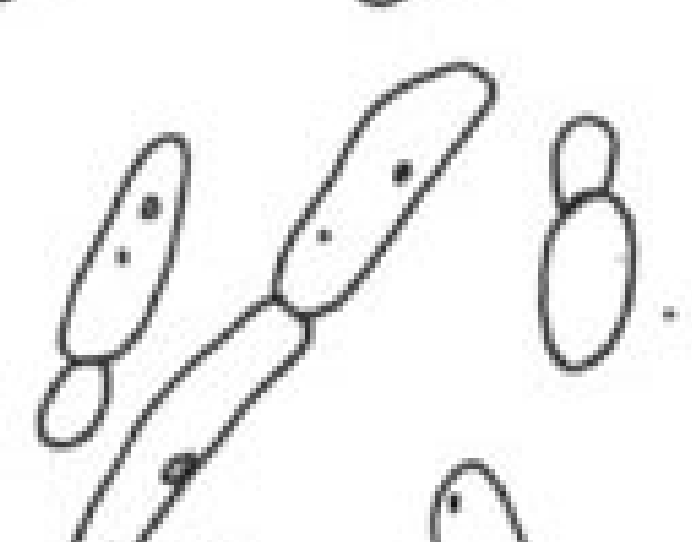

ól. 0

$\circ 8 \circ$

8

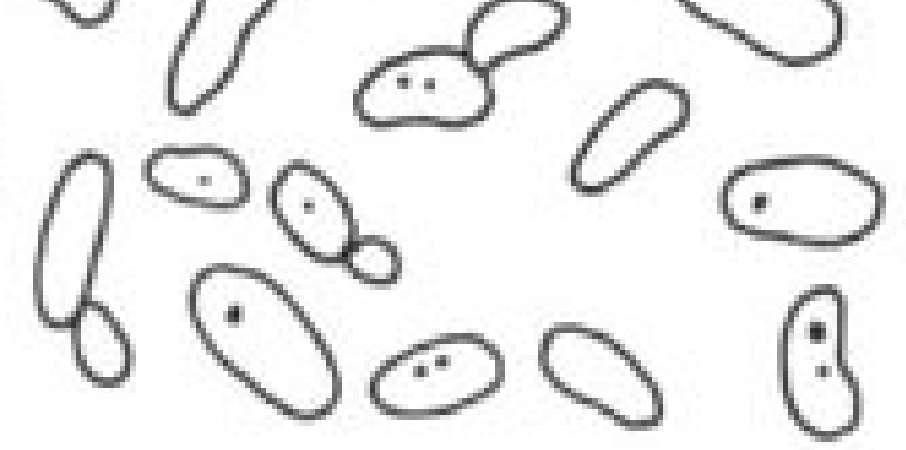
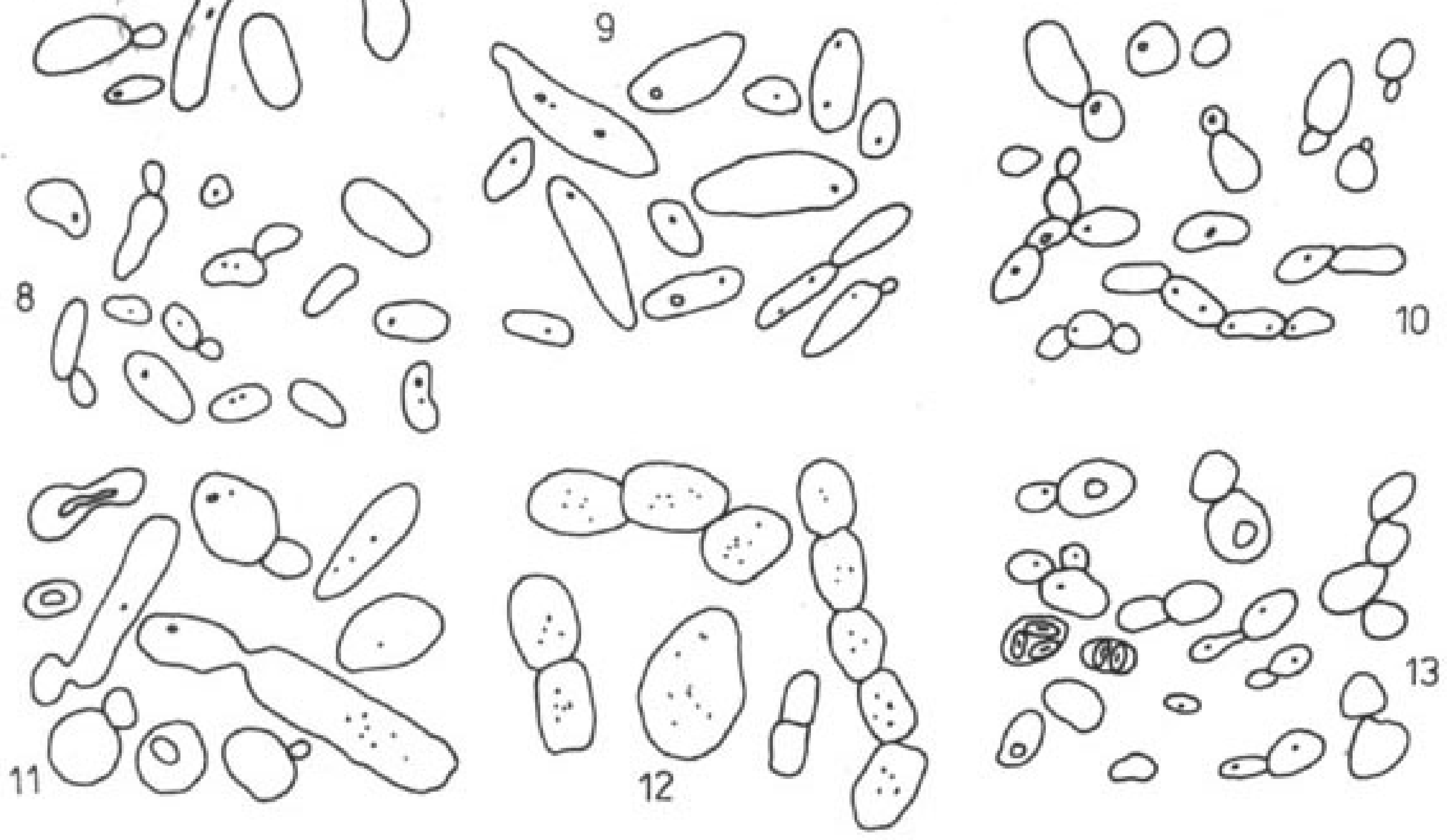

Figs 1-13. Cell morphology $(600 \times)$ :

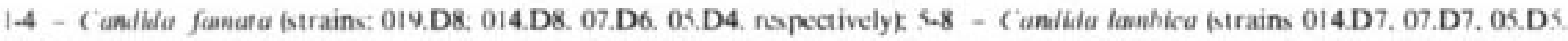

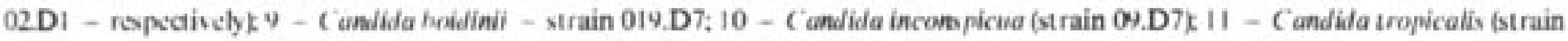

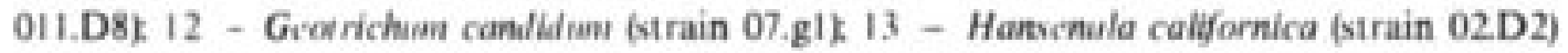



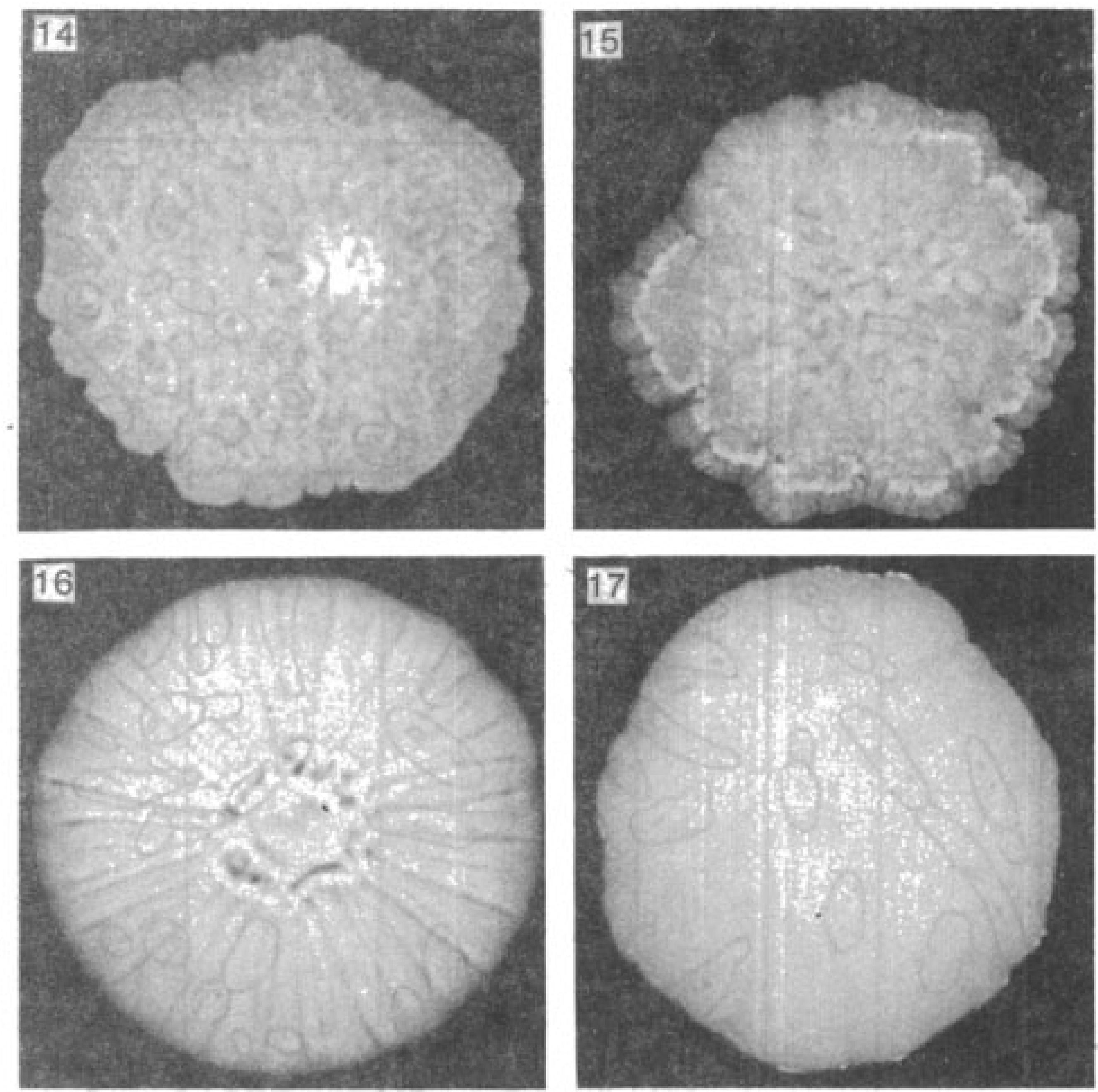

Figs 14-17. Giant colonics:

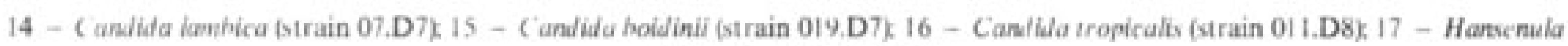
califenica birain 02D2)

Candida hoidinii Ramirez - strain 019.D7 (CCY 29-37-5).

The cells are long-ovoid to cylindrical (Fig. 9). In liquid medium a sediment and a pellicle are formed. Giant colonies are cream - coloured, dull, soft and wrinkled (Fig. 15), rate of growth $4.17 \mathrm{~mm}$ in $100 \mathrm{hrs}$ at $20^{\circ} \mathrm{C}$. Pseudomycelium is abundantly formed. Sporulation was not observed. Urease is not produced. Growth in vitamin-free medium is weak. Grows well at $28^{\circ} \mathrm{C}$, but at $37^{\circ} \mathrm{C}$ does not. Is able to assimilate ethanol and methanol.

Candida inconspicua (Lodder et Kreger-van Rij) Meyer et Yarrow - strain 09.D7 (CCY 26-26-20).

The shape of the cells is ovoid (Fig. 10). In a liquid medium a sediment is formed. The appearance of giant colonies was greyish-white, semidull, soft, smooth, rate of growth $3.72 \mathrm{~mm}$ in $100 \mathrm{hrs}$ at $20^{\circ} \mathrm{C}$. Pseudomycelium is not formed. Sporulation is absent. This organism did not have urease activity and was not able to grow in vitamin-free medium. Grew well at $28^{\circ} \mathrm{C}$. 
Candida tropicalis (Castellani) Berkhout - strain 011.D8 (CCY 29-7-48).

The cells are globose, short-ovoid, to long ovoid (Fig. 11). During the growth in a liquid medium a sediment and a ring are formed. Colonies are cream-coloured, soft and wrink led (Fig. 16), rate of growth $4,63 \mathrm{~mm}$ in $100 \mathrm{hrs}$ at $20^{\circ} \mathrm{C}$. Pseudomycelium is abundantly formed. Sporulation was absent. Urease is not produced. Is able to grow in vitamin-free medium. Growth at 37 and $42^{\circ} \mathrm{C}$ is good.

\section{Geotrichum candidum Link - strain 07.g1 (CCY 16-1-6).}

The shape of the budding cells is ovoid to cylindrical. Usually they are occurring singly or in pairs (Fig. 12). In a culture in liquid medium screeping pellicle and sediment are formed. Giant colonies are expanding, rugose, flat, rate of growth $11.81 \mathrm{~mm}$ in $100 \mathrm{hrs}$ at $20^{\circ} \mathrm{C}$. Pseudomycelium and arthrospores are abundantly formed. Sporulation is absent. Urease is not produced. This organism needed not external vitamins, grew well at $28^{\circ} \mathrm{C}$, at $37^{\circ} \mathrm{C}$, grew too, but weak.

Hansenula californica (Lodder) Wickerham - strain 02.D2 (CCY 38-6-5).

The cells are spheroidal to ellipsoidal, occurring singly or in pairs (Fig. 13). In a culture in liquid medium a sediment is formed, no pellicles. Colonies are greyish-white, moderately glistering (Fig. 17), rate of growth $4.17 \mathrm{~mm}$ in 100 hrs at $20^{\circ} \mathrm{C}$. Pseudomycelium is not formed. During sporulation conjugation occurs between cells and their buds and between independent cells. Asci contain one to four Saturn-shaped ascospores. Urease is not produced. The growth in vitamin-free medium is negative. The strain grows well at $28^{\circ} \mathrm{C}$, but at $37^{\circ} \mathrm{C}$ does not.

Basing on the results of physiological investigations it can be ascertain that yeasts and yeast-like microorganisms isolated from the denitrifying unit were characterized by low sacharolitic activity. Sugars were fermented mainly by $C$. tropicalis. This organism as well as C. famata and Hansenula californica were also able to assimilate those compounds. The investigations carried out indicated that most of the strains are able to utilize aminoacids (lysine and tryptophane) as a nitrogen source whereas nitrates are assimilated by $C$. boidinii and Hansenula californica only. Vitamin requirement of those microorganisms were diversified. Seven strains classified as C. lambica, C. hoidinii, C. inconspicua and Hansenula californica needed vitamins for their growth.

This may suggest that the growth substrate for the fungal microflora were rather compounds released from autolyzed denitrifying bacterial cells then a synthetic mineral medium used as a feed in a course of denitrification process. Nevertheless they did not take part in the nitrate removal process, they could be regarded as a stable component of denitrification unit biocenosis. It was confirmed by the fact that yeast-like microorganisms of the genera Candida and Geotrichum were identified in the denitrification unit biocenosis throughout the period of studies on the removal of nitrates from model medium, that is from 
X.1982 to V.1983. Ycasts of the genus Hansenula were present in the biocenosis only in the months X-XI 1982

From the ecological point of view of particular interest is the fact that above mentioned microorganisms were able to grow in strict anaerobic conditions (redox potential in the denitrification unit was within the range $-100 \div-300$ $\mathrm{mV}$ ).

\section{REFERENCES}

A rx 1. A. 1977. Notes on Dipolascix. Endonjeces and Gtot richus with the description of two new specic. Antonic van Lecuwenhock. 43: 333-340.

Bozko L. Kanska Z. Grabińska-tonicwska A. 1972. Wyodrçbnianic crystych hod owli bakterii / osadu crynnego i badanie ich zdolnosici do klaczk owania. Pr. Nauk. Polit. Warsz Budown: $21-30$.

B ris on L. 1971. Techniques denzymologie bacterienne. Paris.

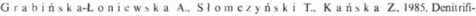
cation studics with glycerol as a carbon source, Wat. Rescarch, 19: 1471.7.

G u c h o E. 1979, Deoxy ribonucleic acid hase composition and taxonomy in the genus Geourichum Link. Antonic van Lecuwenhock. 45; 199-210.

Kr ege r-van R ij N. I. W.. 1984. The yeasts a taxonomic sludy. Amsicrdam.

Koch ova-K r a t o chril orad A. 1977. Cataloguc of Ycast Cultures. Veda. Bratislava. Koch ová-K ratochrilová A.1984. Classification principles for yeast-like genera. Biologia (Bratislava). 39: 717-728.

La n gefon M.. 1945, Precis de Mycologic, Paris.

L o d d e r I. 1970. The Yeasts, a Taxonomic Siudy, Amsterdam.

Stom ezy nski T. G rabińs $k$ a-t on ie ws k a A. 1983, Urzadzenic laboratoryjedo badania procsu usuwania zaniceyszejeri ze scickow w warunkach beztlen owych. Seminaria Nauk. Inst. Inz. Środow. Polit. Warsz: 15\%-165.

St r/ele, y h A. 1968. Metody badania grzybow glebowych. Rocz. Glebozn. 19: 405-424 